BMC

Veterinary Research

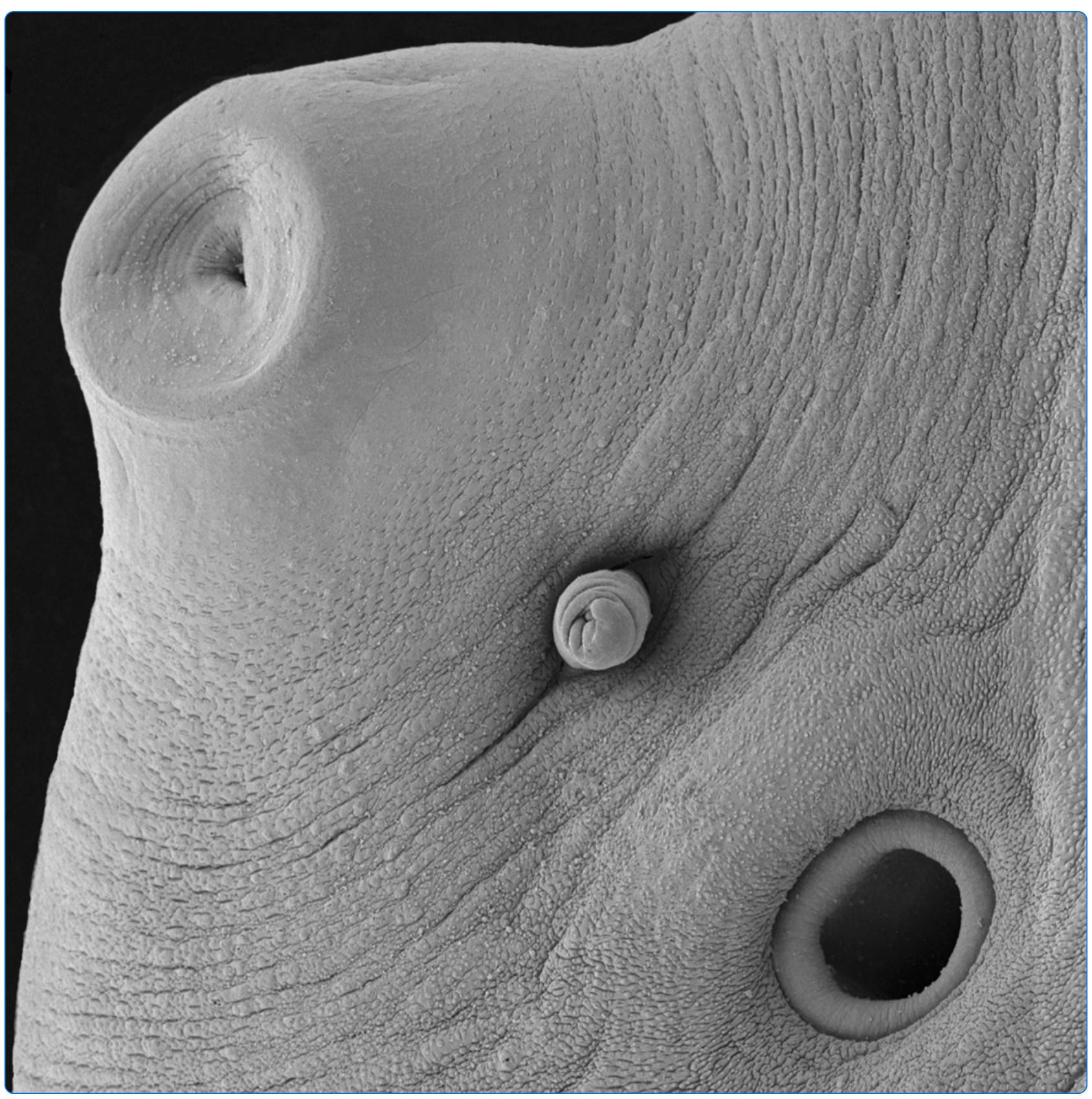

\title{
Highland cattle and Radix labiata, the hosts of Fascioloides magna
}

Leontovyč et al. 


\title{
Highland cattle and Radix labiata, the hosts of Fascioloides magna
}

\author{
Roman Leontovyč , Monika Koštáková', Veronika Siegelová', Klára Melounová', Jan Pankrác ${ }^{1}$, Kristýna Vrbová1, \\ Petr Horák and Martin Kašný ${ }^{1,2^{*}}$
}

\begin{abstract}
Background: Fascioloides magna is a pathogenic fluke introduced to Europe ca 140 years ago. As it is spreading over the continent, new intermediate and definitive hosts might be involved in transmission of the parasite. In Europe, several studies reported potential new intermediate snail hosts (Radix spp.) for F. magna, and also several cases of fascioloidosis of wild and domestic animals were published. However, the data based on molecular and histological analyses confirming these findings remained unreported. This study aims to refer to unique findings of F. magna in European snails and domestic animals (the first observation in the Czech Republic in the last 30 years) and demonstrate the use of molecular techniques in determination of F. magna.
\end{abstract}

Results: Two snails of $R$. labiata naturally infected with F. magna were found; mature cercariae and daughter rediae were observed. Maturity of cercariae was checked by histological methods, however, their ability to encyst was not confirmed. Co-infection of F. magna and Fasciola hepatica in the liver of two highland cattle bulls was proved. Adult fasciolid flukes producing eggs were found in the liver pseudocysts ( $F$. magna) and the bile ducts (F. hepatica). Identification of intermediate hosts, intramolluscan stages, adult flukes and eggs was performed by sequencing the ITS2 region. Connection of F. magna pseudocysts with the gut (via the bile ducts) was not confirmed by means of histological and coprological examinations.

Conclusions: For the first time, Radix labiata was confirmed as the snail host for F. magna under natural conditions and, together with the finding of $F$. magna infection in cattle, we can expect further transmission of F. magna from wild life to livestock in localities shared by these hosts.

Keywords: Fascioloides magna, Fasciola hepatica, Radix labiata, Galba truncatula, Highland cattle, Molecular determination, ITS2, Histology, Pseudocyst

\section{Background}

Fascioloides magna (Bassi, 1875) (Fasciolidae; Digenea; Trematoda) is a large visceral parasite of ruminants originating from North America. Due to the international wild animal trade, F. magna was introduced to Europe in the later half of the $19^{\text {th }}$ century, probably with the white-tailed deer (Odocoileus virginianus) [1] and wapiti (Cervus elaphus canadensis) [2]; the parasite adapted to the local hosts (e.g. red deer, fallow deer) and started to spread. Recent reports from at least six countries in central Europe can be found [3-9].

\footnotetext{
* Correspondence: fascioloides@seznam.cz

${ }^{1}$ Faculty of Science, Department of Parasitology, Charles University in Prague, Viničná 7, Prague 128 44, Czech Republic

${ }^{2}$ Faculty of Science, Department of Botany and Zoology, Masaryk University, Kotlárská 2, Brno 611 37, Czech Republic
}

Like some other digenean trematodes, the F. magna life cycle includes two hosts, aquatic snails as intermediate hosts and ruminants as definitive hosts. In North America as the place of $F$. magna origin, at least five snail species of the family Lymnaeidae producing cercariae being able to form metacercariae were confirmed as the intermediate hosts [10-13]. In Europe only two naturally infected species within the family Lymnaeidae were found - Galba truncatula [1,3,14] and Radix peregra (in the light of recent discoveries, the latter species was probably Radix labiata) $[15,16]$. Only G. truncatula was shown to serve as the natural intermediate host emitting cercariae [1]. Some other lymnaeid snails distributed in the Czech Republic were tested under laboratory conditions as potential intermediate hosts of F. magna. Chroustová et al. [17] obtained cercariae (and 
subsequently infective metacercariae) from experimentally infected Stagnicola palustris. Erhardová-Kotrlá [1] successfully infected Radix peregra peregra and $R$. peregra ovata (according to the current nomenclature probably Radix labiata and Radix balthica) [15,18], nevertheless, only mother rediae were observed. Experimentally infected Lymnaea stagnalis was able to produce a low number of mature cercariae. This was in contrast to a massive exposure of L. stagnalis to miracidia and, therefore, L. stagnalis was considered to be a less susceptible intermediate host of F. magna [19]. Omphiscola glabra and Pseudosuccinea columella can also serve as the intermediate hosts of F. magna [20]. Concerning the latter two snails, there is no report confirming the occurrence of O. glabra in the Czech Republic, but $P$. columella was observed in several biotopes [21]. Since P. columella is a common snail in European greenhouses adapting to the central European climatic conditions [22], potential risk of F. magna transmission via this snail can not be excluded [20].

A wide spectrum of mammals can be infected with F. magna; these animals can generally be divided into three groups with respect to compatibility of the host and the parasite, and pathological impact of the fluke $[11,23,24]$. Successful completion of the F. magna life cycle with eggs released via bile ducts to the host intestine is enabled in "specific definitive hosts" such as red deer (Cervus elaphus), fallow deer (Dama dama) and roe deer (Capreolus capreolus) [1,11]. Infection with F. magna is tolerated by red deer and fallow deer which can survive, usually with hardly distinguishable symptoms, severe infection by hundreds of flukes. On the other hand, for roe deer the infection with a few flukes (less than 10 individuals) can be lethal [1]. The second category - "nonspecific definitive hosts (dead-end hosts)" - is represented e.g. by moose (Alces alces), lama (Lama glama) and cattle (Bos taurus); these animals only exceptionally contribute to spreading of F. magna; the adult flukes can produce eggs, but these are trapped in liver pseudocysts not connected to the bile duct system [25-27]. Pathological impact on the "dead-end hosts" can differ. Whereas Foreyt and Todd [23] and Conboy and Stromberg [28] did not observe any significant health complications in infected animals, Chroustová et al. [17] recorded a reduced weight gain of infected animals (150 g/day). The third category comprises "non-typical hosts (aberrant hosts)" which are sensitive to F. magna infection, e.g., domestic sheep (Ovis aries) and domestic goat (Capra hircus) $[24,28]$; the immature flukes migrate continuously throughout the host body, cause serious damage to various organs, and finally they attack the liver which often leads to death $[11,23]$.

In this paper two unique field findings of $F$. magna are described: larval stages of $F$. magna in the intermediate host $R$. labiata, and adult worms in the "non-specific definitive host" Bos primigenius f. taurus (highland cattle); the latter case is the first report of fascioloidosis in the Czech Republic in the last 30 years. Moreover, we refer to a unique case of co-infection of the same individual definitive host by F. magna and F. hepatica.

\section{Methods}

\section{Ethics statement}

The animals involved in the study were slaughtered in accordance with the regulations and recommendations of the Ministry of Agriculture of the Czech Republic and European Committee (The Veterinary Act 166/1999, EC regulation n. 1099/2009). The samples of the livers were examined by veterinary inspection and with the agreement of the farmers were forwarded to the team members at the Department of Parasitology, Faculty of Science, Charles University in Prague.

\section{Intermediate host (snail) sampling and examination}

In June 2011 and July 2012, Radix spp. snails were collected at a locality with previous findings of $F$. magna Sedliště game reserve [16] (GPS: 49 $32^{\prime} 30.822^{\prime \prime} \mathrm{N} 13^{\circ}$ $38^{\prime} 39.491^{\prime \prime E}$ ). In addition, G. truncatula snails were sampled at the same locality for estimating the prevalence of F. magna in the snail population (see Table 1 for the number of collected snails).

Snails were examined by dissection under stereomicroscope. Infected snails were washed and, together with cercariae and rediae, they were preserved in $96 \%$ ethanol for further molecular determination. In addition, hepatopancreases of infected snails were fixed in Bouin's solution (Sigma-Aldrich) for further histological processing.

The species of snails were predominantly determined by molecular methods (see below). Morphological

Table 1 Examination of Radix and Galba snails for F. magna larvae

\begin{tabular}{|c|c|c|c|c|c|}
\hline Snail species & Year & No. examined & No. infected & Prevalence (\%) & Developmental stage found \\
\hline \multirow[t]{3}{*}{ R. labiata } & 2011 & 155 & 1 & 0.65 & rediae, cercariae \\
\hline & 2012 & 970 & 1 & 0.10 & rediae \\
\hline & total & 1125 & 2 & 0.18 & \\
\hline \multirow[t]{3}{*}{ G. truncatula } & 2011 & 15 & 15 & 100 & rediae, cercariae \\
\hline & 2012 & 35 & 16 & 49 & rediae, cercariae \\
\hline & total & 50 & 31 & 64 & \\
\hline
\end{tabular}


determination was based on morphometry/morphology of the shell and reproduction organs such as bursa copulatrix and its duct $[15,29]$. As morphological characters of reproduction organs can hardly be observed in infected individuals due to their destruction by larval stages of trematodes [30], only uninfected individuals of Radix spp. from the same locality were chosen for morphological determination.

\section{Definitive host (cattle) sampling and examination}

Adult flukes of F. magna and F. hepatica were obtained from dissected livers of naturally infected highland cattle from South Bohemia (Czech Republic). The worms were preserved in 96\% ethanol and Bouin's solution for molecular and histological processing, respectively. Some living individuals were incubated in RPMI 1640 medium (Sigma) at $37^{\circ} \mathrm{C}$ overnight to obtain freshly laid eggs. In addition, coprological examination using the cattle faeces sampled directly from the gut content was performed. After sedimentation/decantation of fecal samples [31], the obtained sediment was examined under microscope and the egg-positive sediment samples were preserved in $96 \%$ ethanol for further molecular determination.

\section{Molecular determination \\ Snails}

DNA was isolated from mechanically homogenized tissue using QIAamp ${ }^{\circ}$ DNA Mini Kit, (QIAGEN). DNA concentration was measured by spectrophotometer ND-1000 $\left(\right.$ NanoDrop ${ }^{\circ}$ ) and then the samples were stored at $-20^{\circ} \mathrm{C}$. PCR was carried out in total volume of $25 \mu \mathrm{l}$ using PPP Master Mix (Top-Bio), 50 ng of snail template DNA and $1 \mu \mathrm{l}$ of $10 \mu \mathrm{M}$ forward primer 5' - TGT GTC GAT GAA GAA CGC AG - 3' and reverse primer 5' - TTC TAT GCT TAA ATT CAG GGG - 3' specific for 502 bp ITS2 region [32].

\section{Flukes}

DNA was isolated from mechanically homogenized adult flukes (as described above for snail samples). Gene specific primers used for amplification of F. magna ITS2 region (152 bp) were designed according to KrálováHromadová et al. [33] and Bazsalovicsová et al. [4] (forward 5'-ACCAGTTATCGTTGTGTTG-3' and reverse 5' -CCGTCTTTAAACAACAG-3').

\section{Eggs}

DNA was isolated using QIAamp ${ }^{\circ}$ DNA Stool Mini Kit (QIAGEN) from F. magna eggs obtained after incubation of living worms, or from sediments of fecal samples. The eggs were homogenized in Bead-Beater (BioSpec) [34]. The same primers and procedure as for the adults were used (see above).
PCR was performed in $\mathrm{C} 1000^{\mathrm{m}}$ Thermal Cycler (Bio$\mathrm{Rad})$ with the following temperature profiles: $94^{\circ} \mathrm{C} 5 \mathrm{~min}$, $30 \mathrm{x}\left(94^{\circ} \mathrm{C}, 30 \mathrm{sec} ; 63^{\circ} \mathrm{C}, 30 \mathrm{sec} ; 72^{\circ} \mathrm{C}, 2 \mathrm{~min}\right), 72^{\circ} \mathrm{C}$, $10 \mathrm{~min}, 4^{\circ} \mathrm{C}$ hold. The obtained PCR products were examined by DNA electrophoresis $\left(1.5 \%\right.$ agarose gel with SYBR ${ }^{\odot}$ Green I, Invitrogen); the gel with amplified DNA was cut out and purified using MinElute Gel Extraction Kit (QIAGEN) and sequenced by using the PCR primers and 3130xl Genetic Analyzer (Applied Biosystems).

All the obtained sequences were adjusted using DNA Star-Lasergene Core Suite software tool and compared with NCBI database using BLAST (Basic Local Alignment Search Tool).

\section{Histology \\ Intermediate hosts}

Hepatopancreas of infected snails was fixed in Bouin's solution (Sigma) and subsequently embedded in JB-4 Plus resin (Polysciences, Inc.). Sections ( $4 \mu \mathrm{m}$ thick) were stained with hematoxylin-eosin.

\section{Definitive hosts}

After macroscopic examination of the host liver, the tissue samples with pathological changes were fixed in $4 \%$ buffered formaldehyde (for hematoxylin-eosin staining) or Bouin's solution (for Gomori trichrome staining) and embedded in paraffin according to standard procedures. Sections ( $5 \mu \mathrm{m}$ thick) were stained and examined under microscope (Olympus BX50).

\section{Results}

\section{Examination of snails and determination of $F$. magna larval stages}

In total, 1155 snails of the genus Radix were examined for fasciolid larval stages; two snails were infected and the prevalence was $0.18 \%$ (Table 1 ). Fifty individuals of G. truncatula from the same locality showed $64 \%$ prevalence. Molecular identification of rediae and mature cercariae showed that in both types of hosts the larvae belong to F. magna.

Radix snails infected with F. magna were determined as $R$. labiata. In addition, morphological characters corresponded to previous descriptions of $R$. labiata $[15,18,29]$ (Figure 1).

\section{Histology of $F$. magna larval stages and snails}

Histological evaluation of the infected snail hepatopancreas of $R$. labiata revealed daughter rediae with developing cercariae, and also free mature cercariae covered by a thick layer of tegument and possessing cystogenous glands full of products (Figure 2A). 


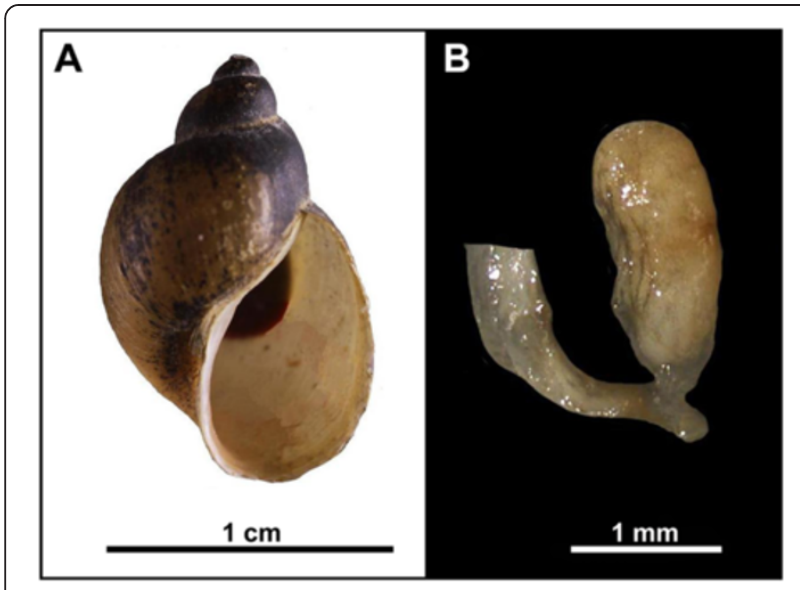

Figure 1 Morphology of Radix labiata, shell (A) and bursa copulatrix (B).

Examination of definitive hosts and determination of F. magna/F. hepatica adults/eggs

In January and September 2012 four three-years old bulls of the highland cattle were slaughtered in the slaughterhouse in South Bohemia. The dissected livers exhibited pathological changes showing the infection by fasciolid flukes - F. hepatica and F. magna (Figures 3, 4 and Table 2). The infected animals were gaunt and in bad physical condition.

\section{Fasciola hepatica}

All adult worms were found in the bile ducts with thickened and calcified walls. Beige mature flukes had maximum size of ca $3 \mathrm{~cm}$ and leaf-shaped body with typical oral cone and "shoulders" (Figure 3). After overnight incubation $\left(37^{\circ} \mathrm{C}\right)$ in RPMI 1640 , thousands of eggs were found and collected. Miracidia hatched after 16 days of incubation $\left(25^{\circ} \mathrm{C}\right)$. Sequential analyses confirmed determination of both $F$. hepatica adults in the bile ducts and the eggs of F. hepatica in the faeces.

\section{Fascioloides magna}

Surface of the infected liver exhibited dark pigmentation associated with migration of juvenile flukes (the same dark lesions were recognized also in the case of $F$. hepatica infection). All individuals were localized in liver pseudocysts filled by a dark suspension of pigment, metabolites and eggs. The flukes had oval shape and reddish brown color. Length of the worms ranged from $3 \mathrm{~cm}$ to $5 \mathrm{~cm}$. Pseudocysts with dead and particularly digested individuals were also observed. During overnight incubation $\left(37^{\circ} \mathrm{C}\right)$ in RPMI 1640, the isolated mature living flukes produced eggs (several times less than F. hepatica); however, these eggs appeared unable to develop - after 16 days of incubation at $25^{\circ} \mathrm{C}$ no miracidia were observed. Sequential analyses confirmed the adult worms as F. magna. No eggs of F. magna were found in faeces.

\section{Discussion}

Two Radix sp. snails naturally infected with fasciolid flukes were found at the locality Sedliště (south Bohemia - Czech Republic), and determined as R. labiata according to the sequence of ITS2 region; daughter rediae and mature cercariae were observed in the snail bodies. This is the first report on Radix sp. snails naturally infected with F. magna when morphological as well as molecular identifications have been performed. Faltýnková et al. [16] referred to a natural infection of $R$. peregra ${ }^{\text {a }}$ with F. magna, but the snail and the parasite determination was based on morphological characters only, and molecular confirmation was missing. Faltýnková et al. [16] collected the snails at the same locality (Sedliště game reserve) and, therefore, it is likely those snails were also

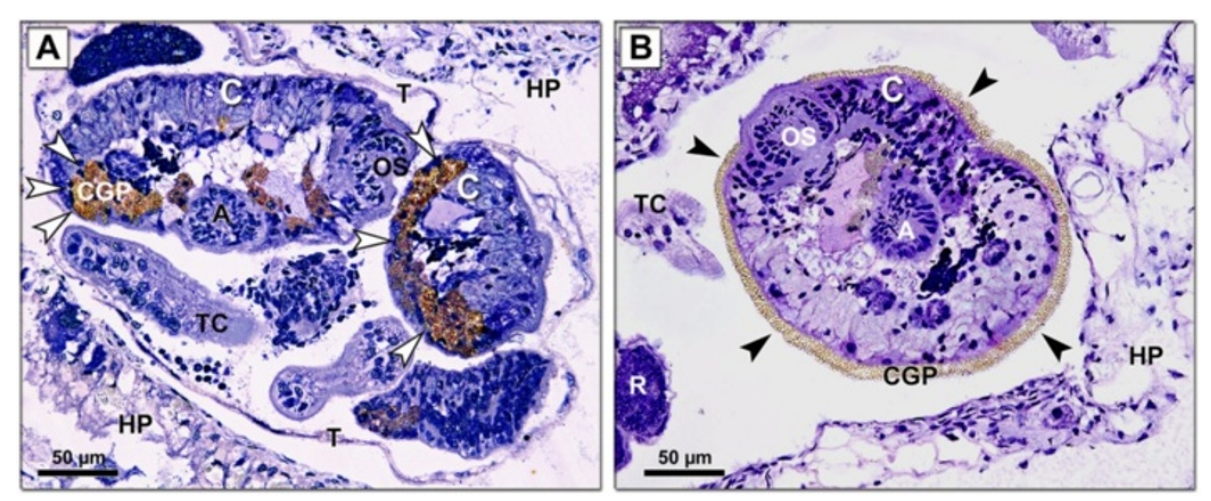

Figure 2 Section of Radix labiata hepatopancreas with Fascioloides magna rediae and immature (A), mature (B) cercariae. Stained with hematoxylin and eosin. HP, hepatopancreas tissue; C, cercaria; R, redia; T, tegument of redia; A, acetabulum; OS, oral sucker; TC, tail of cercaria; CGP, cystogenous gland products. White arrowheads point to cercarialcystogenous glands. Black arrowheads point to cercarial cystogenous products released from the glands. 


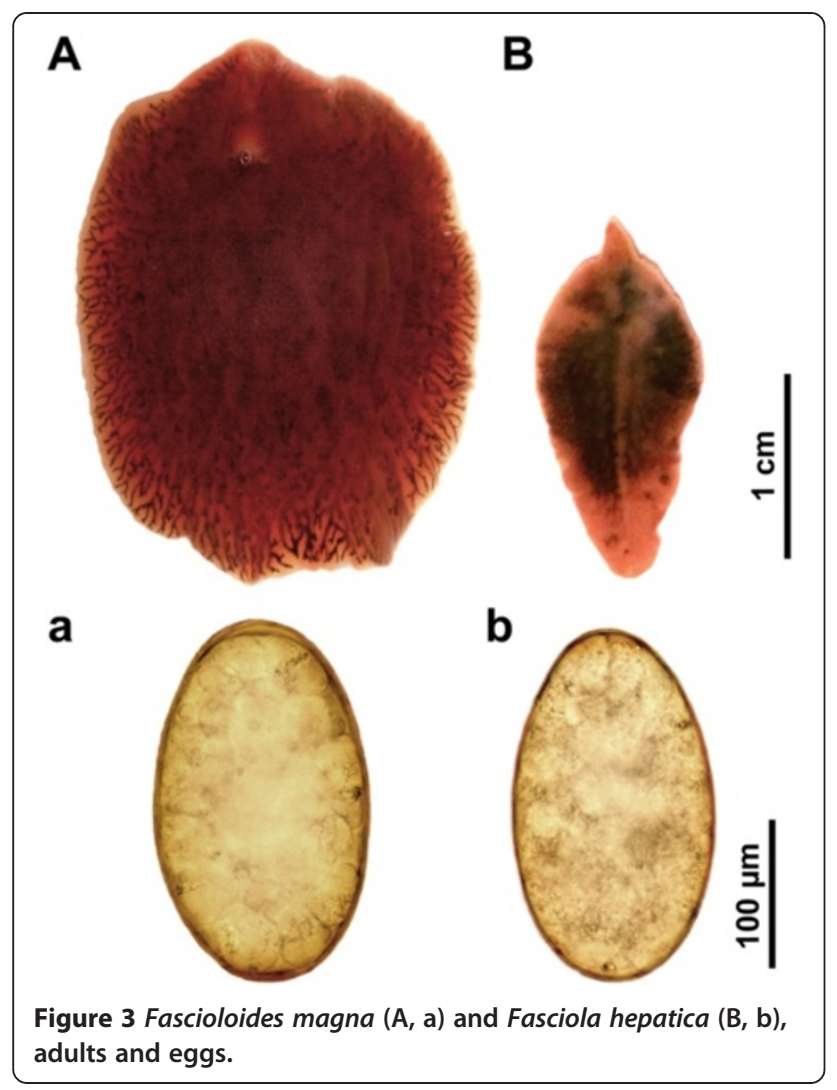

R. labiata as investigated in our study. Moreover, the locality represents a typical biotope for $R$. labiata $[35,36]$. As the snails of the genus Radix occurring at the same locality can be infected with $F$. magna or F. hepatica [16,37], and their intramolluscan stages are morphologically indistinguishable, molecular determination needs to be performed to reach correct results [38]. The snails harboring both flukes were not found at the locality Sedliště. Recently, Huňová et al. [29] performed the first successful experimental infection of $R$. labiata with $F$. magna, followed by molecular identification of the snail and the parasite.

The prevalence of $F$. magna-infected $R$. labiata in Sedliště was $0.18 \%$ (similarly low prevalence from the same locality has been reported by Faltýnková et al. [16]), and the prevalence of infected G. truncatula snails was $64 \%$ (100\% in 2011); such prevalence rate is quite unusual (e.g. [14]) and it indicates a high contamination of the locality by $F$. magna eggs.

Histological evaluation of hepatopancreas from naturally infected snails revealed freely moving cercariae with released cystogenous gland products on their surface (Figure 2). This indicates incorporation of a preparatory phase before encystation of cercariae in the outer environment [39]. However, no cercariae were able to encyst, probably because they were obtained artificially by dissection. Similar results were obtained by ErhardováKotrlá [1], Faltýnková et al. [16] and Huňová et al. [29] in experimental infections of $R$. labiata with $F$. magna .

Two species of fasciolid flukes were found in the livers of two bulls of highland cattle; a typical localization of the flukes - bile ducts (F. hepatica) and fibrous pseudocysts (F. magna) - was observed. Morphological characters served for parasite determination, and identity of both species was subsequently verified by molecular methods. In the past, only one report on co-localized fasciolid flukes in one liver of cattle was published [25]. Coprological examination performed in our study revealed a high number of fasciolid eggs which were indistinguishable according to their morphology $[1,40]$. By applying molecular methods only the eggs of $F$. hepatica were determined. This finding corresponds to the literary data on pseudocysts that in the case of "non-specific definitive hosts (dead-end host)" are not connected via the bile ducts with the host gut, and the eggs accumulate

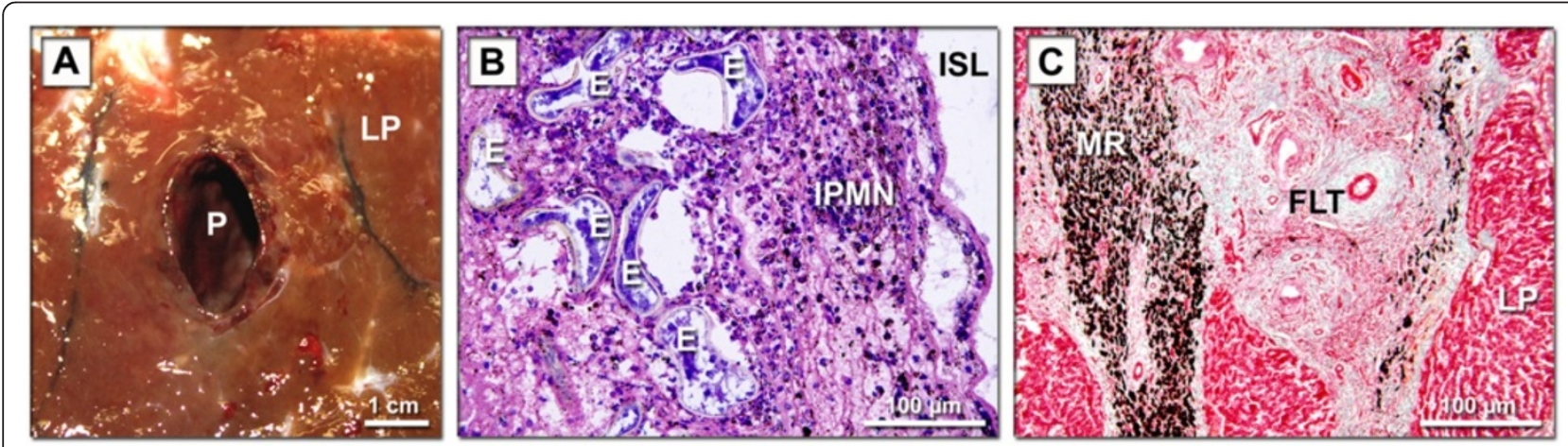

Figure 4 Pathological changes in bovine liver caused by F. magna infection. A, macroscopic photo of dissected liver tissue; B, microscopic photo - section of lesion with eggs and inflammatory infiltrate of polymorphonuclear leukocytes, stained with hematoxylin and eosin; C, microscopic photo - section of fibrotic portobiliar space and adjacent liver parenchyma, stained with green Gomori trichrome. P, pseudocyst; $L P$, liver parenchyma; E, egg of F. magna; IPMN, infiltrate of polymorphonuclear leukocytes; ISL, inner space of lesion; MR, migratory route through parenchyma with pigment deposits caused by F. magna juvenile worms; FLT, fibrotic liver tissue. 
Table 2 Examination of livers from slaughtered highland cattle for $F$. magna adults

\begin{tabular}{ccccc}
\hline & & F. hepatica & F. magna & $\begin{array}{c}\text { F. magna } \\
\text { (dead worms) }\end{array}$ \\
\hline January 2012 & Bull 1 & 130 & 5 & 0 \\
& Bull 2 & 187 & 0 & 0 \\
September 2012 & Bull 3 & 60 & 0 & 0 \\
& Bull 4 & 50 & 2 & 5 \\
\hline
\end{tabular}

in pseudocysts $[23,28]$. However, some exceptions may occur, e.g., Erhardová-Kotrlá [1] experimentally infected cattle and recorded eggs in the faecal samples, although in a low number. Balbo et al [9] and Foreyt and Todd [41] noticed a low number of eggs of $F$. magna in the faeces of naturally infected cattle. Foreyt and Todd [41] believed that the eggs may appear due to rupture of pseudocyst. Absence of eggs in the faeces of "non-specific definitive hosts (dead-end host)" complicates intravital diagnosis: it is impossible to apply routine coprological examination and, therefore, serological or other techniques should be used as an alternative.

Pathological impact of F. magna infection on cattle is questionable. Conboy and Stromberg [28] focused on analysis of blood samples. In addition, liver enzyme activities were monitored. These enzymes are probably a sensitive marker of liver damage by $F$. hepatica [42-44], however, in case of $F$. magna no significant difference between infected and uninfected individuals was recorded. Moreover, the infection (contrary to F. hepatica infection) did not affect the weight gain [45]. Besides cattle, also guinea pigs served for experimental infections. Although all the infected animals died and the pathological impact was evident, most of the monitored parameters were comparable to the control [28]. This implies that fascioloidosis is a serious disease with hardly observable diagnostic markers. In our study both bulls were in bad condition (e.g., chronic cachexy was mentioned in the veterinary report). We can speculate that it was probably due to $F$. hepatica infection, because in the liver of each bull at least $130 \mathrm{~F}$. hepatica adult worms were found, whereas the number of $F$. magna adults was up to 10 individual flukes.

The infected bulls came from a South Bohemian biofarm with restricted therapeutic intervention and ideal natural condition for transmission of F. magna, e.g., wet pastures, natural streamlet and no effective fences. Erhardová-Kotrlá [1] carried out detailed research in the same locality and marked this locality as F. magna free after 6 cattle postmortem examinations and 282 examinations of the red deer faecal samples. Therefore, our results indicate that F. magna can spread in the Czech Republic.

\section{Conclusion}

Two unique records of snail intermediate hosts ( $R$. labiata) and mammalian definitive hosts (bulls of highland cattle) naturally infected with $F$. magna are reported in our study. Molecular techniques were used to confirm host/parasite determination; on this basis the adults of $F$. magna were discriminated from $F$. hepatica presented in the same liver. In addition, species identity of the morphologically uniform fasciolid eggs was proved. The prevalence of $F$. magna in $R$. labiata was comparable to some findings of $F$. magna in G. truncatula and, therefore, R. labiata might represent a potential vector of $F$. magna in localities ecologically unsuitable for G. truncatula (e.g. localities with acid soils). Ability of the parasite to be transmitted from wildlife to livestock represents a serious risk, especially for farmers breeding the animals less tolerant to F. magna infection (e.g., goats and sheep), and those animals whose are for some reason (e.g. ecological farming) under restrictions in terms of anthelmintic treatment. Therefore, the danger of $F$. magna transmission should be taken into account in farm management.

\section{Endnotes}

${ }^{a} R$. peregra is the taxonomic name which has generally been used by Czech malacologists. According to the results of generally accepted phylogenic analyses, $R$. peregra is synonymous with $R$. labiata which represents a valid taxon. In Western Europe the name of $R$. peregra was also used, but for different species currently named as $R$. balthica, see Schniebs et al. [15,18].

${ }^{\mathrm{b}}$ Metacercariae of $F$. magna were found on the wall of Petri dish after dissection of experimentally infected R. labiata (Pankrác 2013, unpublished), but experimental infection of a definitive host was not performed.

\section{Competing interests}

The authors declare that they have no competing interests.

\section{Authors' contributions}

$\mathrm{RL}$ - designed the study, participated in field collections, carried out morphological and molecular identification of snails and parasites, wrote the main parts of the manuscript; MKo - participated in field collections, carried out the analyses of histological samples; VS, KM - helped with molecular identification of snails and parasites; JP, KV - participated in field collections, helped with examination of snails; $\mathrm{PH}$ - helped with writing of the manuscript and interpretation of the data; MKa - designed the study, participated in field collections, coordinated laboratory work, helped with writing. All authors have read and approved the final manuscript.

\section{Acknowledgements}

This project was partially supported by the Charles University in Prague (GAUK 502313, UNCE 204017, PRVOUK P41, SW 267210/2013). The authors thank the farmers from the South Bohemian Biofarm.

Received: 3 July 2013 Accepted: 28 January 2014

Published: 11 February 2014

\section{References}

1. Erhardová-Kotrlá B: The Occurence of Fascioloides magna (Bassi, 1875) in Czechoslovakia. Prague: Academia; 1971:1-124. 
2. Bassi R: Sulla cachessia ittero-verminosa, o marciaia, causata dal Distomum magnum. Medico Vet Torino 1875(11-12):497-515. S.4, v.4

3. Kašný $M$, Beran L, Siegelová V, Siegel $T$, Leontovyč R, Beránková K, Pankrác J, Koštáková M, Horák P: Geographical distribution of the giant liver fluke (Fascioloides magna) in the Czech Republic and potential risk of its further spread. Vet Med (Praha) 2012, 57:101-109.

4. Bazsalovicsová E, Král'ová-Hromadová I, Špakulová M, Reblánová M, Oberhauserová K: Determination of ribosomal internal transcribed spacer 2 (ITS2) interspecific markers in Fasciola hepatica, Fascioloides magna, Dicrocoelium dendriticum and Paramphistomum cervi (Trematoda), parasites of wild and domestic ruminants. Helminthologia 2010, 47:76-82

5. Král'ová-Hromadová I, Bazsalovicsová E, Štefka J, Špakulová M, Vávrová S, Szemes T, Tkach V, Trudgett A, Pybus M: Multiple origins of European populations of the giant liver fluke Fascioloides magna (Trematoda: Fasciolidae), a liver parasite of ruminants. Int J Parasitol 2011, 41:373-383.

6. Ursprung J, Joachim A, Prosl $\mathrm{H}$ : Incidence and control of the American giant liver fluke, Fascioloides magna, in a population of wild ungulates in the Danubian wetlands east of Vienna. Berl Münch Tier Woch 2006, 119:316-323.

7. Majoros G, Stojkov V: Appearance of the large American liver fluke Fascioloides magna (Bassi, 1875) (Trematoda: Fasciolata) in Hungary. Parasitol Hung 1994, 28:27-38.

8. Rajkovic-Janje R, Bosnic S, Rimac D, Gojmerac T: The prevalence of American liver fluke Fascioloides magna (Bassi 1875) in red deer from Croatian hunting grounds. Eur J Wildlife Res 2008, 54:525-528.

9. Balbo T, Lanfranchi P, Rossi L, Meneguz P: Health management of a red deer population infected by Fasciololoides magna (Bassi, 1875) Ward, 1917 (1). Ann Fac Med Vet Torino 1987, 32:23-33.

10. Sinistin DF: The life histories of some American liver flukes. $Z$ Parasiten 1933, 6:170-191

11. Swales WE: The life cycle of Fascioloides magna (Bassi, 1875), the large liver fluke of ruminants in Canada with observations on the bionomics of the larval stages and the intermediate hosts, pathology of Fascioloidiasis magna, and control measures. Can J Res 1935, 12:177-215

12. Griffiths HJ: Stagnicola (Hinckleyia) caperata (Say), a Natural Intermediate Host for Fascioloides magna (Bassi, 1875), in Minnesota. J Parasitol 1959, 45:146.

13. Laursen JR, Stromberg BE: Fascioloides magna intermediate snail hosts: habitat preferences and infection parameters. J Parasitol 1993, 79:302.

14. Haider M, Hörweg C, Liesinger K, Sattmann H, Walochnik J: Recovery of Fascioloides magna (Digenea) population in spite of treatment programme? Screening of Galba truncatula (Gastropoda, Lymnaeidae) from Lower Austria. Vet Parasitol 2012, 187:445-451.

15. Schniebs K, Glöer P, Vinarski MV, Hundsdoerfer AK: Intraspecific morphological and genetic variability in the European freshwater snail Radix labiata (Rossmaessler, 1835) (Gastropoda : Basommatophora: Lymnaeidae). Contrib Zool 2013, 82:55-68.

16. Faltýnková A, Horáčková E, Hirtová L, Novobilský A, Modrý D, Scholz T: Is Radix peregra a new intermediate host of Fascioloides magna (Trematoda) in Europe? Field and experimental evidence. Acta Parasitol 2006, 51:87-90.

17. Chroustová E, Hůlka J, Jaroš J: 1980 Chroustová - Prevalence a terapie fascioloidózy skotu bithionosulfoxidem. Vet Med (Praha) 1980, 25:557-563.

18. Schniebs K, Glöer P, Vinarski MV, Hundsdoerfer AK: Intraspecific morphological and genetic variability in Radix balthica (Linnaeus 1758) (Gastropoda: Basommatophora: Lymnaeidae) with morphological comparison to other European Radix species. J Conchol 2011, 40:657-678.

19. Griffiths HJ: Galba modicella and Lymnaea stagnalis as experimental intermediate hosts for Fascioloides magna in Minnesota. J Parasitol 1973, 59:121.

20. Rondelaud D, Novobilský A, Vignoles P, Treuil P, Koudela B, Dreyfuss G: First studies on the susceptibility of Omphiscola glabra (Gastropoda: Lymnaeidae) from central France to Fascioloides magna. Parasitol Res 2006, 98:299-303.

21. Horsák M, Dvořák $L$, Juřičková L: Greenhouse gastropods of the Czech Republic: current stage of research. Malacol News 2004, 22:141-147.

22. Pointier JP, Coustau C, Rondelaud D, Theron A: Pseudosuccinea columella (Say 1817) (Gastropoda, Lymnaeidae), snail host of Fasciola hepatica: first record for France in the wild. Parasitol Res 2007, 101:1389-1392.

23. Foreyt WJ, Todd AC: Development of the large American liver fluke, Fascioloides magna, in whitetailed deer, cattle, and sheep. J Parasito 1976, 62:26-32.
24. Pybus MJ: Liver flukes. In Parasitic Diseases in Wild Mammals. lowa: lowa State University Press; 2001:121-149.

25. Foreyt WJ, Todd AC: The occurrence of Fascioloides magna and Fasciola hepatica together in the livers of naturally infected cattle in south Texas, and the incidence of the flukes in cattle, white-tailed deer, and feral hogs. J Parasitol 1972, 58:1010-1011.

26. Lankester MV: Parelaphostrongylus tenis (Nematoda) and Fascioloides magna (Trematoda) in moose of southeastern Manitoba. Can J Zool 1974 52:235-239.

27. Naem S, Budke CM, Craig TM: Morphological characterization of adult Fascioloides magna (Trematoda: Fasciolidae): first SEM report. Parasito Res 2012, 110:971-978.

28. Conboy GA, Stromberg BE: Hematology and clinical pathology of experimental Fascioloides magna infection in cattle and guinea pigs. Vet Parasitol 1991, 40:241-255.

29. Huňová K, Kašný M, Hampl $V$, Leontovyč R, Kuběna A, Mikeš L, Horák P: Radix spp.: identification of trematode intermediate hosts in the Czech Republic. Acta Parasitol 2012, 57:273-284.

30. Wilson RA, Denison J: The parasitic castration and gigantism of Lymnaed truncatula infected with the larval stages of Fasciola hepatica. Parasitol Res 1980, 61:109-119.

31. Anh NT, Phuong NT, Ha GH, Thu LT, Johansen MV, Murrell DK, Thamsborg SM: Evaluation of techniques for detection of small trematode eggs in faeces of domestic animals. Vet Parasitol 2008, 156:346-349.

32. Almeyda-Artigas RJ, Bargues MD, Mas-Coma S: ITS-2 rDNA sequencing of Gnathostoma species (Nematoda) and elucidation of the species causing human gnathostomiasis in the Americas. J Parasitol 2000, 86:537-544.

33. Král'ová-Hromadová I, Špakulová M, Horáčková E, Turceková L, Novobilský A, Beck R, Koudela B, Marinculić A, Rajský D, Pybus M: Sequence analysis of ribosomal and mitochondrial genes of the giant liver fluke Fascioloides magna (Trematoda: Fasciolidae): intraspecific variation and differentiation from Fasciola hepatica. J Parasitol 2008, 94:58-67.

34. Harmon AF, Zarlenga DS, Hildreth MB: Improved methods for isolating DNA from Ostertagia ostertagi eggs in cattle feces. Vet Parasitol 2006, 135:297-302.

35. Ložek V: Klíc Československých Měkkýšủ. Bratislava. Vydavatel'stvo Slovenskej akadémie vied; 1956:437.

36. Jackewicz M: Blotniarki Europy (Gastropoda: Pulmonata: Lymnaeidae). Poznań, Poland: Wydawnictwo Kontekst; 2000:115.

37. Relf V, Good B, McCarthy E, Waal T: Evidence of Fasciola hepatica infection in Radix peregra and a mollusc of the family Succineidae in Ireland. Vet Parasitol 2009, 163:152-155.

38. Caron Y, Lasri S, Losson B: Fasciola hepatica: an assessment on the vectorial capacity of Radix labiata and $R$. balthica commonly found in Belgium. Vet Parasitol 2007, 149:95-103

39. Dixon KE: A morphological and histochemical study of the cystogenic cells of the cercaria of Fasciola hepatica L. Parasitology 1966, 56:287-297.

40. Špakulová M, Rajský D, Vodňanský J, Sokol J: Giant liver fluke (Fascioloides magna), an important liver parasite of ruminants. Bratislava: Parpress; 2003:61.

41. Foreyt WJ, Todd AC: Efficacy of rafoxanide and oxyclozanide against Fascioloides magna in naturally infected cattle. Am J Vet Res 1974, 35:375-377.

42. Simesen MG, Nielsen K, Nansen P: Some effects of experimental Fasciola hepatica infection in cattle on the serum activities of gammaglutamyltranspeptidase and glutamic oxaloacetic transaminase. Res Vet Sci 1973, 15:32-36

43. Anderson PH, Berrett S, Brush PJ, Hebert CN, Parfitt JW, Patterson DJ: Biochemical indicators of liver injury in calves with experimental fascioliasis. Vet Rec 1977, 100:43-45.

44. Anderson PH, Berrett S, Patterson DJ: Resistance to Fasciola hepatica in cattle II. Biochemical and morphological observations. J Comp Pathol 1978, 88:245-251.

45. Zmuda K, Chroust K: Motoličnatost skotu v okrese Frýdek-Místek. Veterinarstvi 2001, 51:181-183.

doi:10.1186/1746-6148-10-41

Cite this article as: Leontovyč et al:: Highland cattle and Radix labiata, the hosts of Fascioloides magna. BMC Veterinary Research 2014 10:41. 